\title{
Primary Systemic Amyloidosis
}

National Cancer Institute

\section{Source}

National Cancer Institute. Primary Systemic Amyloidosis. NCI Thesaurus. Code C8299.

A plasma cell neoplasm that secretes an abnormal immunog lobulin, which deposits in various tissues and forms a beta-pleated sheet structure that binds Congo red dye with characteristic birefringence. The sites of involvement include heart, liver, kidney, gut, tongue, nerves, and bone. (WHO, 2001) 